\author{
Alina Grynia \\ Katedra Nauk Historyczno-Prawnych, Wydział Prawa \\ Uniwersytet w Białymstoku
}

\title{
WSPÓŁPRACA TRANSGRANICZNA LITWA-POLSKA-ROSJA: ROZWÓJ ORAZ PERSPEKTYWY
}

\section{Wstęp}

Współpraca regionów granicznych, którą najczęściej określa się mianem transgranicznej, ma w Europie bogaty dorobek oraz wieloletnią historię. Stała się ona nieodzownym czynnikiem stymulującym rozwój regionów ze względu na wielorodność problemów po obu stronach granic państw na tym kontynencie.

Rozwój współpracy w Europie Środkowej i Wschodniej umożliwiły przemiany ustrojowe lat osiemdziesiątych i dziewięćdziesiątych. Wraz z przystąpieniem Polski i Litwy do UE wschodnia granica tych krajów stała sięjednocześnie granicą całej UE. Wówczas współpraca z regionami państw Europy Wschodniej oraz Federacji Rosyjskiej nabrała nowego znaczenia. Społeczność lokalna po obu stronach granic znalazła się w obliczu wielu nowych wyzwań. Konieczny był w tym kontekście rozwój współpracy przygranicznej, rozbudowa infrastruktury granicznej, a także wymiana informacji i doświadczeń. Jak wskazuje doświadczenie UE, większe możliwości stworzenia sprawnie działających mechanizmów współpracy występują w skali regionu. Tutaj najłatwiej można znaleźć punkty styczne dla priorytetów społecznych, politycznych i gospodarczych.

Celem niniejszego opracowania jest omówienie podstawowych przesłanek i form współpracy transgranicznej oraz jej genezy. Szczególną uwagę zwrócono na przebieg współpracy transgranicznej Polski i Litwy z Federacją Rosyjską. Analizę tego rodzaju programów podzielono na dwa okresy programowe: 20042006 i2007-2013. Zwrócono uwagę na zmiany w koncepcji polityki współpracy w UE, celów tej współpracy oraz wysokości i zasad finansowania. Opracowanie kończy przegląd podstawowych korzyści współpracy dla regionów przygranicznych. 


\section{Przesłanki rozwoju współpracy transgranicznej}

Przez pojęcie „współpraca transgraniczna” rozumie się „każde wspólnie podjęte działanie mające na celu umocnienie i dalszy rozwój sąsiedzkich kontaktów między wspólnotami i władzami terytorialnymi dwóch lub większej liczby Umawiających się Stron, jak również zawarcie porozumień i przyjęcie uzgodnień koniecznych do realizacji takich zamierzeń". Powyższa definicja została zaczerpnięta z Europejskiej konwencji ramowej o współpracy transgranicznej między wspólnotami i władzami terytorialnymi, dokumentu Rady Europy podpisanego 21 maja 1980 r. w Madrycie.

Podobne rozumienie tego terminu proponuje się w Europejskiej karcie regionów granicznych i transgranicznych wydanej w 1981 r. przez Stowarzyszenie Europejskich Regionów Granicznych. W tym dokumencie „,współpracę transgraniczną” określa się jako współpracę zarówno sąsiedzką - przylegających do siebie regionów granicznych, jak i zagraniczną - władz szczebla regionalnego i lokalnego, organizacji lub instytucji reprezentujących obszary graniczne. Podkreśla się, że współpraca transgraniczna odnosi się nie tylko do działań władz lokalnych czy regionalnych, lecz także do wspólnych inicjatyw przedsiębiorstw, organizacji i mieszkańców².

Można więc mówić, iż współpraca transgraniczna jest szczególnym przypadkiem współpracy międzynarodowej, której charakterystycznymi cechami są sąsiedzkość kontaktów oraz lokalny lub regionalny poziom współdziałania. Władze lokalne mogą zawierać umowy wyłącznie w ramach swoich kompetencji, a współpraca powinna być nawiązywana z poszanowaniem prawa krajowego oraz zobowiązań międzynarodowych państwa.

Z powyższych definicji wynika, iż współpraca transgraniczna może przebiegać na różnych poziomach, przybierać odmienne formy i dotyczyć różnych sfer życia społeczno-gospodarczego. Może to być na przykład współpraca dwóch gmin tworzących związki partnerskie zwane bliźniaczymi. Za najbardziej zinstytucjonalizowaną formę uważa się e uroreg i on $\mathrm{y}^{3}$ działające na podstawie porozumień między władzami szczebla lokalnego oraz regionalnego, a w niektórych przypadkach także z udziałem podmiotów gospodarczych i społecznych. W latach dziewięćdziesiątych euroregiony zaczęły powstawać na zewnętrznych granicach Wspólnoty, z udziałem podmiotów z krajów Europy Środkowej i Wschodniej. Wśród samorządów państw regionu największą aktywność w rozwoju współpracy wykazały samorządy polskie, gdzie euroregiony zaczęły powstawać żywiołowo, wyprzedzając uregulowania prawne. Pierwszy euroregion - Nysa - po-

${ }^{1}$ Dz. U. z dnia 10 lipca 1993 r.

2 Portal Polskiego Instytutu Spraw Międzynarodowych, Biuletyn nr 24, 9.06.2004 [online], http://www.pism.pl/biuletyn_content/id/18 (dostęp: 15.12.2010).

${ }^{3}$ Region transgraniczny można określić jako łączne terytorium podlegające kompetencjom władz lokalnych i regionalnych biorących udział w inicjatywach INTERREG. Zob.: S. Dołzbłasz, A. Raczyk, Wspótpraca transgraniczna w Polsce po akcesji do UE, Warszawa 2010, s. 17. 
wstał na pograniczu polsko-niemiecko-czeskim w 1991 r., a obecnie kilkanaście struktur tego typu funkcjonuje w Polsce wzdłuż całej granicy. Celem współpracy $\mathrm{w}$ euroregionach jest wzajemne podejmowanie i koordynowanie korzystnych działań w zakresie gospodarki, nauki, kultury, oświaty oraz rozwijanie i ułatwianie kontaktów mieszkańców i podmiotów gospodarczych ${ }^{4}$.

Analizując kontakty transgraniczne, można zauważyć, że zmianie ulegały nie tylko formy i zasady, ale też główne cele współpracy. Tak np. zasadniczą przesłanką nawiązania współpracy zaraz po II wojnie światowej było zmniejszenie antagonizmów i zbliżenie sąsiadujących narodów. Z czasem dostrzeżono korzyści gospodarcze takiej współpracy, a nieco później zaczęto ją traktować także jako czynnik wspierający integrację i rozwijający kontakty na pograniczach.

Istotna dla rozwoju kontaktów transgranicznych jest zmiana funkcji granic. Przestały one odgradzać, stając się przede wszystkim granicami administracyjnymi. Ich charakter przekłada się wyraźnie na charakter i intensywność współpracy. Ważnym czynnikiem integrującym jest rozbudowa infrastruktury komunikacyjnej oraz usuwanie przeszkód w przepływie osób, towarów i usług. Łatwość przemieszczania się jest ważna nie tylko ze względów społecznych, lecz także gospodarczych i politycznych.

Wsparcie finansowe współpracy transgranicznej ze strony UE zaczęło się w latach dziewięćdziesiątych, szczególnie przez program INTERREG.

\section{Podstawowe pojęcia z zakresu współpracy terytorialnej}

Współpraca transgraniczna jest jednym z elementów polityki regionalnej UE. Dąży ona do podwyższenia poziomu spójności w trzech wymiarach: gospodarczym, społecznym i terytorialnym ${ }^{5}$. Wzrost spójności gospodarczej polega na zmniejszeniu zróżnicowań na poziomie rozwoju gospodarczego pomiędzy obszarami bogatymi a biednymi. Jest ona mierzona za pomocą produktu krajowego brutto na mieszkańca. Natomiast wzrost spójności społecznej polega na zmniejszaniu zróżnicowań w wykorzystaniu kapitału ludzkiego pomiędzy poszczególnymi obszarami. Spójność ta jest mierzona za pomocą wskaźnika stopy bezrobocia, ale coraz częściej jako miernik uwzględnia się również stopę partycypacji ${ }^{6}$. Wreszcie trzecim wymiarem spójności jest spójność terytorialna lub inaczej przestrzenna, którą mierzy się czasem przejazdu do danego obszaru komunikacją lotniczą, drogową i kolejową. Wzrost spójnóści terytorialnej polega na eliminowaniu barier dostępności do regionów peryferyjnych poprzez ich lepsze powiązanie z obszarami centralnymi UE.

${ }^{4}$ Wspótpraca transgraniczna $w$ Europie [online], http://www.stat.gov.pl/cps/rde/xbcr/wroc/ ASSETS_14-19.pdf (dostęp: 5.12.2010).

${ }^{5}$ Portal Funduszy Strukturalnych [online], http://www.ewt.gov.pl/ (dostęp: 2.12.2010).

${ }^{6}$ Miernik ten określa, jaka część ludności w wieku produkcyjnym znajduje zatrudnienie. 
Jest to zatem polityka UE służąca wzmacnianiu spójności gospodarczej i społecznej poprzez zmniejszenie dysproporcji w poziomie rozwoju różnych regionów. Polega ona przede wszystkim na pomocy w formie dotacji dla regionów. Podstawowymi instrumentami polityki spójności są F undu s ze S trukturalne i Fundusz Spójności (dalej: FS) ${ }^{7}$. Do funduszy strukturalnych zalicza się Europejski Fundusz Społeczny (dalej: EFS) i Europejski Fundusz Rozwoju Regionalnego (dalej: EFRR). Natomiast FS ma niejako dopełniać zadania realizowane przez fundusze strukturalne. Cechą charakterystyczną FS jest to, że zajmuje się on projektami dotyczącymi infrastruktury komunikacyjnej i ochrony środowiska o wartości powyżej $10 \mathrm{mln}$ euro. Zasadniczą różnicą między tymi funduszami jest to, że FS jest wdrażany na poziomie państw członkowskich, a nie regionów czy sektorów.

Wspomniane dotacje w okresie 2007-2013 są kierowane na realizację trzech najważniejszych celów ${ }^{8}$ :

1) konwergencji, czyli spójności - polega na wsparciu finansowym państw i regionów najmniej rozwiniętych, których poziom PKB na jednego mieszkańca wynosi poniżej 75\% średniej unijnej ${ }^{9}$. Cel ten jest ukierunkowany na poprawę wzrostu zatrudnienia czy też przyjęcie koncepcji społeczeństwa opartego na wiedzy. Państwa zakwalifikowane do tego celu, mogą korzystać z funduszy EFS, EFRR i FS, a wysokość finansowania kształtuje się na poziomie ok. 81,5\% wszystkich wydatków w ramach funduszy strukturalnych;

2) podniesienia konkurencyjności regionów i zatrudnienia - cel ten jest skierowany do państw, które przekroczyły poziom 75\% PKB średniej unijnej, ale nadal nie są na tyle rozwinięte, by radzić sobie we własnym zakresie. W ramach tego celu UE wspiera innowacje i badania naukowe, zrównoważony rozwój oraz szkolenia zawodowe w mniej rozwiniętych regionach. Wymienione działania są finansowane głównie z EFRR i EFS, a środki przeznaczone na ten cel wynoszą blisko $16 \%$ całości środków polityki spójności;

3) europejskiej ws półpracy terytorialnej-polega na wspieraniu, promocji i realizacji wspólnych projektów o charakterze międzynarodowym na terytorium całej UE. Cel ten jest współfinansowany tylko przez EFRR, a na jego realizację przeznacza się ok. 2,5\% środków polityki spójności. Beneficjentami w tym przypadku są także zewnętrzne regiony graniczne UE.

$Z$ racji obranej tematyki niniejszego opracowania na szczególną uwagę zasługuje Europejska Współpraca Terytorialna (dalej: EWT), ostatni cel polityki spójności, który w nowym okresie programowym (2007-2013) zastąpił funkcjonującą dotychczas Inicjatywę Wspólnoty - INTERREG III ${ }^{10}$. Nowy

\footnotetext{
${ }^{7}$ Różnica między tymi funduszami powoli się zaciera, gdyż są one regulowane tym samym rozporządzeniem Rady Europy, a mianowicie nr 1083/2006 z dnia 11 lipca 2006 r.

${ }^{8}$ Portal Funduszy Europejskich [online], http://www.ewt.gov.pl/ (dostęp: 2.12.2010).

${ }^{9}$ Poziom ten jest obliczany za 3 lata wstecz.

10 Celem Inicjatywy Wspólnotowej INTERREG w latach 2004-2006 było wspieranie współpracy przygranicznej, międzynarodowej i międzyregionalnej zarówno na zewnętrznych, jak
} 
instrument polityki spójności będzie się składał, podobnie jak INTERREG III, z trzech komponentów, takich jak:

- programy współpracy transgranicznej $\rightarrow$ (zastąpiły INTERREG IIIA);

- programy współpracy transnarodowej $\rightarrow$ (zastąpiły INTERREG IIIB);

- programy współpracy międzyregionalnej (INTERREG IVC) $\rightarrow$ (zastąpiły INTERREG IIIC).

Na uwagę zasługuje fakt, iż współpraca terytorialna wykraczająca poza granice UE $\mathrm{w}$ obecnym okresie programowania może być realizowana $\mathrm{w}$ ramach Europejskiego Instrumentu Sąsiedztwa i Partnerstwa (dalej: EISiP) oraz Instrumentu W sparcia Przedakcesyjnego ${ }^{11}$ (dalej: IWP). Oba instrumenty zawierają elementy współpracy transgranicznej, współfinansowane $\mathrm{z}$ EFRR.

Całkowite dostępne zasoby przeznaczone na fundusze strukturalne w okresie 2007-2013 wynoszą 308,041 mld euro (w cenach z 2004 r.) lub 347,410 mld euro (w aktualnych cenach). Zgodnie z przepisami stosownych rozporządzeń środki na cel EWT wynoszą 2,52\% tych zasobów, tzn. kwotę nieco ponad 7,75 mld euro ${ }^{12}$.

\section{Przebieg współpracy między Polską, Litwą i Rosją}

\section{Początki współpracy i okres programowy 2004-2006}

Historia współpracy Polski, Litwy i Rosji sięga lat pięćdziesiątych. Do początków lat dziewięćdziesiątych Obwód Kaliningradzki oraz Republika Litewska wchodziły w skład Związku Radzieckiego, ich nie dzieliły granice państwowe, a łączyły ścisłe powiązania i związki instytucjonalne, liczne kontakty między organizacjami i osobami prywatnymi. Sytuacja taka zapewniała dobre relacje między Litwą i Obwodem Kaliningradzkim. Natomiast w przypadku Polski i Rosji na obszarze kwalifikowanym współpraca zaczęła rozwijać się w aktywny sposób dopiero w latach dziewięćdziesiątych. Pierwsze przejście graniczne Braniewo-Mamonowo pomiędzy Polską a Obwodem Kaliningradzkim zostało otwarte w 1990 r. W tym czasie Litwa ogłosiła niepodległość i w ten sposób powstała granica rosyjsko-litewska. W efekcie Obwód Kaliningradzki stał się rosyjską eksklawą, obecnie całkowicie otoczoną przez terytoria państw UE i Morze Bałtyckie.

Nowa granica UE z państwami Europy Wschodniej - Rosją, Białorusią i Ukrainą - obejmuje ok. 3000 km. Poszczególne odcinki granicy z tymi państwa-

\footnotetext{
i wewnętrznych granicach UE. W ramach INTERREG III wydzielone zostały trzy komponenty: komponent A - współpraca przygraniczna; komponent B - współpraca transnarodowa; komponent C - współpraca międzyregionalna w skali europejskiej. Szerzej na ten temat: Portal Funduszy Strukturalnych - INTERREG [online], http://www.interreg.gov.pl/Co+to+jest+INTERREG+III/ (dostęp: 3.12.2010).

${ }^{11}$ Instrument finansowy IWP wprowadzono w 2007 r. w zastępstwie unijnych programów i środków pomocowych wobec krajów kandydujących lub potencjalnych kandydatów.

${ }^{12}$ Dz. Urz. UE L 210 z 31.07.2006, s. 25.
} 
mi mają kluczowe znaczenie dla UE ze względów bezpieczeństwa, ekonomicznych oraz społecznych. Najważniejsze z nich dotyczą problemu tzw. „miękkiego bezpieczeństwa" (związanego z przemytem, nielegalną migracją, przestępczością zorganizowaną itp. $)^{13}$. Ponadto przez granicę tę przebiegają prawie wszystkie najważniejsze korytarze transportowe i szlaki komunikacyjno-handlowe łączące Europę z obszarem Eurazji.

Dodać tu należy, iż cechą charakterystyczną obszarów po obu stronach nowej granicy wschodniej UE jest ich peryferyjność. W zdecydowanej większości są to tereny rolnicze o znacznie gorszych wskaźnikach ekonomicznych niż reszta kraju. $\mathrm{W}$ podobnym stopniu dotyczy to regionów po obu stronach granicy. Są one niedoinwestowane, $\mathrm{z}$ dużo wyższym od średnich krajowych poziomem bezrobocia, bez dużych ośrodków przemysłowych ${ }^{14}$. Peryferyjność jednak w dużym stopniu sprzyja rozwijaniu kontaktów transgranicznych, wzajemnemu budowaniu nowego typu potencjałów gospodarczych. Ze względu na bezpośrednie sąsiedztwo UE z trzema państwami Europy Wschodniej o bardzo dużym potencjale ekonomiczno-społecznym oraz kluczowo położonych geopolitycznie zaistniała konieczność wzmocnienia i budowania programów wspierających wspólpracę międzyregionalną i transgraniczną.

Współpraca transgraniczna na tym pograniczu od samego początku koncentrowała się na wspólnych problemach sąsiadujących ze sobą regionów, mając na celu uczynienie ich bardziej konkurencyjnymi i atrakcyjnymi. Władze polskich i litewskich obszarów sąsiadujących z Obwodem Kaliningradzkim zawarły ze swoimi kaliningradzkimi odpowiednikami porozumienia o stałej współpracy. Powołano do życia euroregiony - Niemen i Bałtyk ${ }^{15}$.

W ramach sieci euroregionalnych zostały zrealizowane liczne działania i projekty na poziomie regionalnym i lokalnym. Euroregiony były także wykorzystywane do administrowania funduszami unijnymi przeznaczonymi, z różnych linii budżetowych, na rozwój regionalny i współpracę transgraniczną. Łączna wartość przyznanej pomocy finansowej w latach 1998-2005 przekroczyła 8,9 mln euro w przypadku Euroregionu Bałtyk i 13,2 mln euro w przypadku Euroregionu Niemen, co miało przełożenie na realizację odpowiednio 240 i 279 projektów ${ }^{16}$.

${ }^{13}$ M. Wolarska, I. Zabielska, Wspótpraca Polski z Obwodem Kaliningradzkim Federacji Rosyjskiej na przełomie XX i XXI wieku, [w:] Rozwój wspótpracy gospodarczej Polski z nowymi krajami czlonkowskimi UE oraz z Rosja, Ukraina i Białorusia, red. J. Misala, Radom 2007, s. 251-252.

${ }^{14} \mathrm{~B}$. Grużewski, A. Grynia, J. Wołkonowski, Determinants of free labour force movement in the Euroregion Niemen, [w:] Gospodarowanie zasobami pracy na poczatku XXI w. Aspekty makroekonomiczne i regionalne, red. R. Cz. Horodeński, C. Sadowska-Snarska, Białystok-Warszawa 2009, s. 190-210.

${ }^{15}$ Euroregion Niemen powstał w 1997 r., a Bałtyk w 1998 r. Obejmują one samorządy z obszarów głównych Programu: Kłajpeda, Taurogi, Marijampol, województwa warmińsko-mazurskie, podlaskie i pomorskie oraz Obwód Kaliningradzki. Szerzej na ten temat w opracowaniu T. Palmowskiego, Wspótpraca z Obwodem Kaliningradzkim Federacji Rosyjskiej jako czynnik rozwoju regionalnego [online], http://www.mrr.gov.pl/rozwoj_regionalny/poziom_regionalny/strategia_rozwoju_polski_wschodniej_do_2020/dokumenty/Documents/e9c8e43c89544a13ab940a1 a192ee58aPalmowski.pdf (dostęp: 5.12.2010).

${ }_{16}$ Cross-border Cooperation Programme Lithuania-Poland-Russia 2007-2013 [online], http://www.lt-pl-ru.eu/pl,1,9 (dostęp: 3.12.2010). 
Współpraca terytorialna nabrała rozpędu po rozszerzeniu UE w 2004 r. Wówczas został uruchomiony nowy program wsparcia dla Obwodu Kaliningradzkiego i regionalnych sąsiadów z Litwy i Polski - Program Sąsiedztwa Litwa-PolskaObwód Kaliningradzki Federacji Rosyjskiej finansowany z EFRR. Mieści się on w komponencie A, na który przypadło najwięcej środków. Podział środków INTERREG III alokowanych dla Polski w latach 2004-2006 przedstawiał się następująco $^{17}$ :

- komponent A - 80\% całości (177,09 mln euro);

- komponent B - 14\% ogółu (30,99 mln euro);

- komponent $\mathrm{C}-6 \%$ (13,28 mln euro).

Podział środków w ramach komponentu A według granic Polski pokazuje, iż największe fundusze przypadły na programy realizowane na granicy zachodniej. Istotne jest także finansowanie programów na granicy wschodniej - nie mniej niż $35 \%$ środków przeznaczonych na komponent $\mathrm{A}^{18}$ :

- granica wschodnia - min. 35\% środków, tj. 61,98 mln euro;

- granica południowa - 28,5 mln euro;

- granica zachodnia - 86,60 mln euro.

Obszary wsparcia w ww. programie zostały wydzielone na poziomie NUTS III $^{19}$. Po stronie polskiej to 8 podregionów: słupski, gdański, Gdańsk-Gdynia-Sopot, elbląski, olsztyński, ełcki, białostocko-suwalski i łomżyński. Po stronie litewskiej 4 regiony: Klaipėda, Taurage, Alytus i Marijampolè, natomiast Federację Rosyjską reprezentował cały obszar Obwodu Kaliningradzkiego (zob. rys. 1).

Program Sąsiedztwa Polska-Litwa-Federacja Rosyjska był skierowany do jednostek samorządu terytorialnego i ich związków, partnerów społeczno-ekonomicznych, instytucji edukacyjnych i kulturalnych, organizacji pozarządowych itp. Jego celem było wspieranie współpracy transgranicznej na północno-wschodniej granicy Polski stanowiącej jednocześnie zewnętrzną granicę UE. Wyróżniono trzy podstawowe priorytety trójstronnej współpracy ${ }^{20}$.

Pri o ry te t 1. Wzrost konkurencyjności i produktywności obszaru wspótpracy poprzez modernizacje i rozbudowe infrastruktury transgranicznej, ochro-

17 Portal Funduszy Strukturalnych - INTERREG [online], http://www.interreg.gov.pl/ Co+to+jest+INTERREG+III/ (dostęp: 3.12.2010).

${ }^{18}$ Problemy rozwoju przygranicznych regionów wschodniej Polski, red. C. Sadowska-Snarska, Białystok 2002, s. 40-42.

19 Nomenclature Units for Territorial of Statistics (NUTS) obowiązuje w krajach UE i oznacza Klasyfikację Jednostek Terytorialnych do Celów Statystycznych. Została ona ustanowiona w celu zbierania, opracowania i rozpowszechniania na obszarze UE porównywalnych danych dla określonych statystyk regionalnych. Podstawowym kryterium klasyfikacji jednostek NUTS jest stan ludności. Dla NUTS III dolna granica stanu ludności wynosi 150 tys., natomiast górna - 800 tys. Szerzej w: Główny Urząd Statystyczny. Portal Informacyjny [online], http://www.stat. gov.pl/gus/5840_7551_PLK_HTML.htm (dostęp: 15.12.2010).

${ }^{20}$ Cross-border Cooperation Programme Lithuania-Poland-Russia [online], http://www.ltpl-ru.eu/pl,1,9 (dostęp: 12.12.2010). 
ne granic oraz wspótprace gospodarcza i naukowo-techniczna. W ramach tego priorytetu mieszczą się takie działania, jak wspieranie współpracy gospodarczej i naukowo-technicznej, wzmocnienie infrastruktury granicznej i przygranicznej w celu zapewnienia rozwoju obszaru przygranicznego, ochrona środowiska, wzrost efektywności wykorzystania energii, promowanie odnawialnych źródeł energii; lub rozwój turystyki i infrastruktury turystycznej przyczyniający się do rozwoju obszaru przygranicznego, a także zachowanie obiektów dziedzictwa kulturowego o znaczeniu transgranicznym.

P r i o r y te t 2. Wspólpraca pomiędzy społecznościami, integracja społeczno-kulturowa, wzmocnienie rynku pracy. Kwalifikowane są tu działania dotyczące wspierania inicjatyw społeczności lokalnych oraz zachowania dziedzictwa kulturowego.

Pri o r y te t 3. Pomoc techniczna. Dotyczy to działań związanych z zarządzaniem, wdrażaniem i promocją programu.

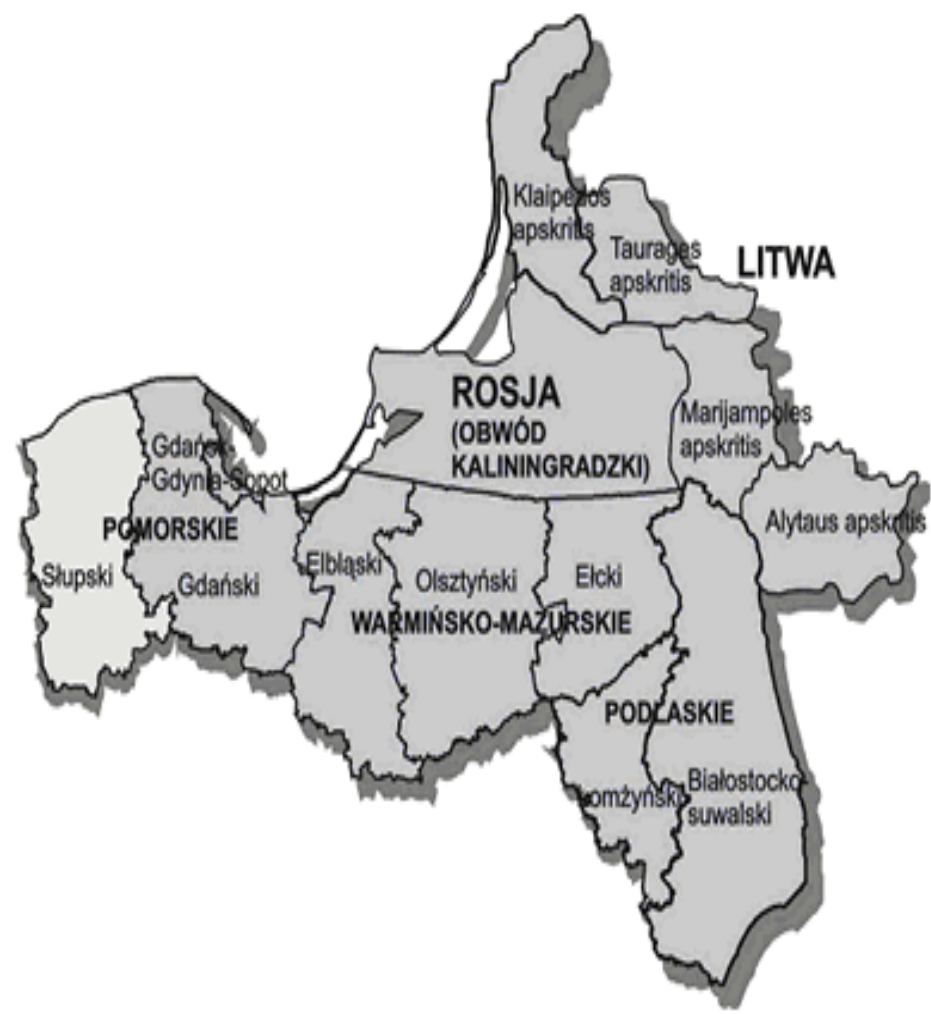

Rys. 1. Obszary kwalifikowane w Programie Sąsiedztwa Polska-Litwa-Federacja Rosyjska (Obwód Kaliningradzki) INTERREG IIIA

Źródło: Portal Funduszy Strukturalnych - INTERREG IIIA [online], http://www.interreg.gov. pl/INTERREG+IIIA/Program+Polska++Litwa++Federacja+Rosyjska+Obwod+Kaliningradzki/ (dostęp: 3.12.2010). 
Program otrzymał wsparcie w wysokości przekraczającej 44,5 mln euro (36,5 mln euro z EFRR i $8 \mathrm{mln}$ z Tacis), co zaowocowało 162 projektami w ramach dwóch priorytetów ${ }^{21}$.

Od połowy lat dziewięćdziesiątych liczba inicjatyw, w których uczestniczyły regiony obszaru kwalifikowanego, stale rosła. Brały one udział w szeregu projektów strategicznych realizowanych wspólnie, m. in. dotyczących współpracy na obszarze Delty Wisły i Zalewu Wiślanego. Oprócz tego uczestniczyły w kilku projektach transnarodowych mających na celu na przykład poprawę transportu morskiego Baltic Gateway czy rozwoju transnarodowego Łuk Południowego Bałtyku. Współpraca odbywa się w ramach organizacji, instytucji i inicjatyw regionalnych, m. in. takich jak Wizje i Strategie wokół Morza Bałtyckiego (VASAB), Ars Baltica, Subregionalna Współpraca Państw Morza Bałtyckiego (BSSSC), Konferencja Peryferyjnych Regionów Morskich Europy - Komisja Bałtycka (BSC CPMR), Związek Miast Bałtyckich (UBC), Bałtycki Związek Instytucji Rozwoju Regionalnego (BARDI). Politycznym zwornikiem tej współpracy jest Rada Państw Morza Bałtyckiego (CBSS), a w szerszym sensie Wymiar Północny jako ramy współpracy w szczególności między UE a Rosją 22 .

\section{Okres programowy 2007-2013}

Kolejny, zakończony w 2004 r. etap rozszerzenia UE, wywołał potrzebę wypracowania nowej koncepcji politycznej dla krajów sąsiadujących z poszerzoną Unią. Komunikat KE „Ustanawiając drogę do Nowego Instrumentu Sąsiedztwa”, konkretyzował założenia nowego Europejskiego Instrumentu Sąsiedztwa i Partnerstwa postulowanego w komunikacie ,Wider Europe"23. W lipcu 2006 r. Parlament Europejski przyjął sprawozdania dotyczące Europejskiego Instrumentu Sąsiedztwa i Partnerstwa oraz Instrumentu Pomocy Przedakcesyjnej. Trzy miesiące później zostało przyjęte rozporządzenie ustanawiające ostatecznie Europejski Instrument Sąsiedztwa i Partnerstwa ${ }^{24}$.

Jak już było mówione w początkowej części danego opracowania, obecnie współpraca transgraniczna jest realizowana w ramach celu 3. polityki spójności UE. Najważniejszymi elementami nowej zasady współpracy terytorialnej są ${ }^{25}$ :

${ }^{21}$ Tamże.

${ }^{22}$ Program wspótpracy transgranicznej Litwa-Polska-Rosja 2007-2013.Dokument programowy [online], http://www.ewt.gov.pl/WstepDoFunduszyEuropejskich/Documents/1Program_LT_PL_RU_ zatw_przez_KE.pdf (dostęp: 10.12.2010).

${ }^{23}$ Communication from the Commission to the Council and the European Parlament, Wider Europe - Neighbourhood: A New Framework for Relations with our Eastern and Southern Neigh-

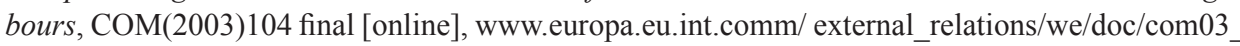
104 en.pdf (dostęp: 10.12.2010).

${ }^{24}$ Dz. U. UE L 310/1 z 9.11.2006.

25 Portal Ministerstwa Rozwoju Regionalnego [online], http://www.mrr.gov.pl/aktualnosci/ rozwoj_regionalny/Strony/Polityka_spojnosci_UE2007_2013.aspx (dostęp: 5.12.2010). 
- elastyczność (10\%) - umożliwia przesuwanie środków między komponentem współpracy transgranicznej i transnarodowej;

- 75\% współfinansowania ze środków wspólnotowych we wszystkich trzech komponentach;

- obszary kwalifikujące się do wsparcia - regiony na poziomie NUTS III, ze względu na porównywalność statystyk ( $20 \%$ środków będzie wydatkowane na projekty w przyległych regionach NUTS III, lecz jedynie w państwach członkowskich);

- regiony zewnętrzne (państwa spoza UE) objęte pomocą jedynie w ramach ISiP i IWP;

- regiony morskie - nowym rozwiązaniem jest zdefiniowanie regionów morskich kwalifikujących się do współpracy transgranicznej. Kiedy są położone w odległości większej niż $150 \mathrm{~km}$, mogą podejmować współpracę bilateralną w ramach komponentu ponadnarodowego;

- wydatkowanie środków w państwie trzecim - środki w ramach komponentu transgranicznego mogą być wydatkowane na realizację projektów na terytorium państwa trzeciego do wysokości $10 \%$ alokacji EFRR na program, pod warunkiem, że będą one miały korzystne oddziaływanie dla regionów UE. Odpowiedzialność za te wydatki spoczywa na partnerze wiodącym z UE i instytucji certyfikującej;

- programy transgraniczne są realizowane na granicy lub w obrębie kilku granic;

$-\mathrm{n}+2-\mathrm{w}$ stosunku do programów celu 3 . ma zastosowanie zasada $\mathrm{n}+2$.

Wyznaczenie obszarów kwalifikujących się do wsparcia w ramach współpracy terytorialnej EWT oparto na podobnych zasadach, jak w odniesieniu do INTERREG IIIA. Do realizacji współpracy wzięto pod uwagę regiony Wspólnoty na poziomie NUTS III położone wzdłuż jej wszystkich wewnętrznych i niektórych zewnętrznych granic lądowych, a ponadto wszystkie regiony NUTS III położone wzdłuż granic morskich ${ }^{26}$. Na terenie Polski uwzględniono ten sam podział na jednostki NUTS III, co w przypadku programu INTERREG IIIA ${ }^{27}$.

W ramach programu współpracy transgranicznej Litwa-Polska-Rosja finansowaniem są objęte podregiony:

- w Polsce: białostocko-suwalski, łomżyński, ełcki, olsztyński, elbląski, Gdańsk-Gdynia-Sopot, gdański, a także jako tzw. podregiony przyległe: słupski, bydgoski, toruńsko-włocławski, ciechanowsko-płocki, ostrołęcko-siedlecki;

- na Litwie: Marijampolè, Taurage, Klaipėda, a także jako podregiony przyległe: Alytus, Kowno, Telsiu, Siauliu;

- w Rosji: Obwód Kaliningradzki.

Obecnie są wyróżnione dwa priorytety programu, a w ich ramach wyszczególniono następujące działania ${ }^{28}$ :

${ }^{26}$ Dz. Urz. UE L 210 z 31.07.2006, s. 25.

${ }^{27}$ Dz. U. 2004, Nr 58, poz. 685.

${ }^{28}$ Program wspótpracy transgranicznej Litwa-Polska-Rosja 2007-2013..., s. 15-17. 
Priorytet 1. Przyczynianie się do rozwiąywania wspólnych problemów i wyzwań:

Działanie 1.1. Zrównoważone wykorzystanie środowiska;

Działanie 1.2. Poprawa dostępności.

Priorytet 2. Wspieranie rozwoju społecznego, gospodarczego i przestrzennego:

Działanie 2.1. Rozwój turystyki;

Działanie 2.2. Rozwój potencjału ludzkiego poprzez poprawę warunków społecznych, rządzenia i szans edukacyjnych;

Działanie 2.3. Zwiększenie konkurencyjności MŚP i rozwój rynku pracy;

Działanie 2.4. Wspólne planowanie przestrzenne i społeczno-ekonomiczne.

Budżet Programu na lata 2007-2013 ze środków Europejskiego Instrumentu Sąsiedztwa i Partnerstwa sięga 132,13 mln euro. Strona rosyjska zdecydowała o przeznaczeniu do budżetu Programu kwoty ok. 44 mln euro z własnych środków.

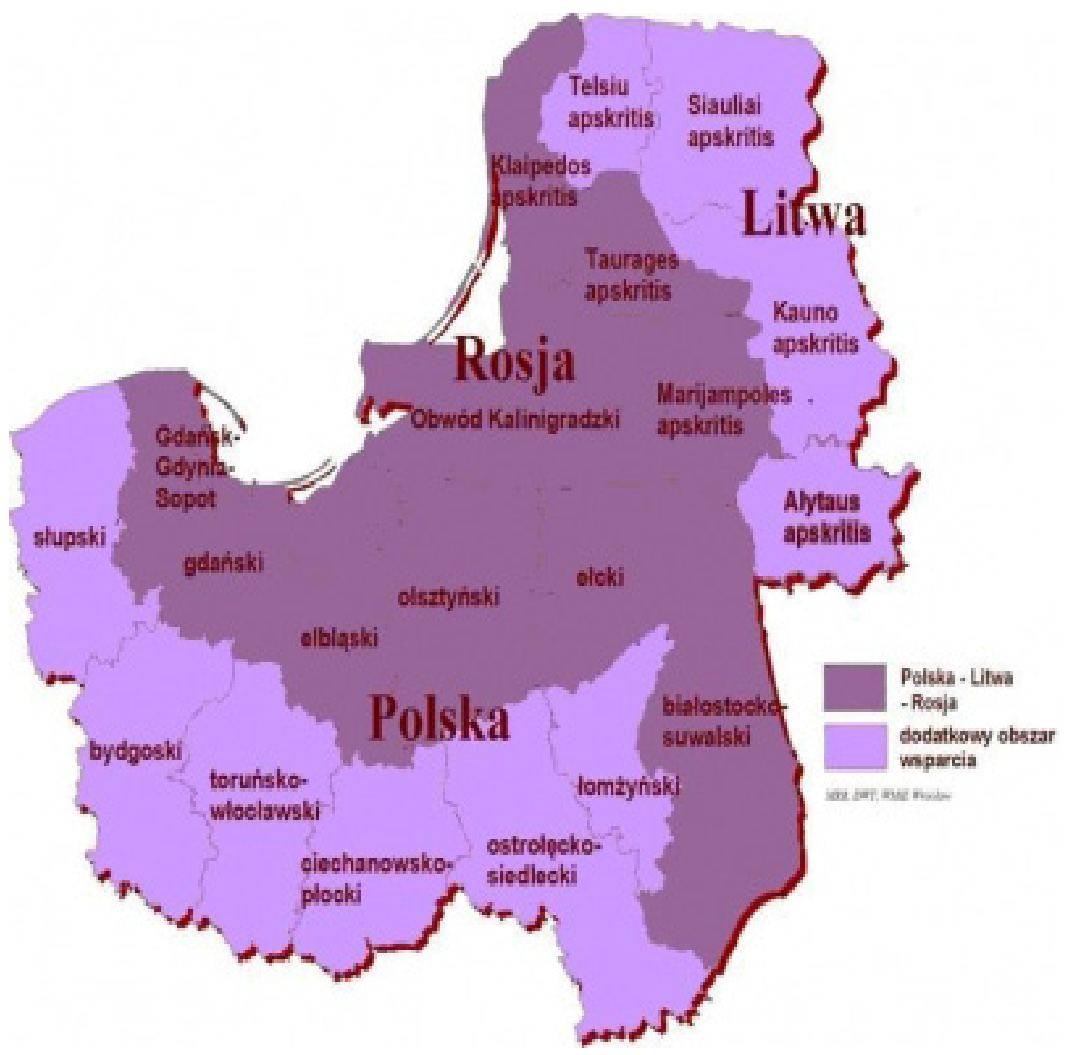

Rys. 2. Obszar wsparcia programu Polska-Litwa-Federacja Rosyjska w okresie 2007-2013

Źródło: Portal Centrum Projektów Europejskich [online], http://www.cpe.gov.pl/4,lt-pl-ru (dostęp: 10.12.2010). 


\section{Ocena wspólpracy transgranicznej}

Pomimo niewielkiej skali programów współpracy transgranicznej w latach 2004-2006 w Europie odnotowano znaczącą wartość bezpośrednich efektów uzyskanych w niektórych obszarach: zrealizowano ponad 18 tys. projektów, w ramach których zorganizowano ponad 1,5 mln spotkań, wydarzeń, kampanii promocyjnych i informacyjnych, wystaw, targów, ustanowiono prawie 12 tys. sieci, platform wymiany, partnerstw i innych struktur współpracy, zbudowano ponad 100 tys. km ciągów komunikacyjnych (drogowych, kolejowych, wodnych, pieszych i rowerowych) ${ }^{29}$.

Na podstawie badań cząstkowych, przeprowadzonych na zlecenie Ministerstwa Rozwoju Regionalnego w podziale na poszczególne granice, dokonano analizy całego programu INTERREG IIIA realizowanego w Polsce ${ }^{30}$. Wynika z niej, iż kwoty alokowane na programy współpracy zostały praktycznie w całości wykorzystane (97,4\% dla programu Litwa-Polska-Rosja). Zatem z punktu widzenia zdolności absorpcyjnej program odniósł sukces. Widoczne było również zainteresowanie beneficjentów. Badacze wskazują, że projektodawcy najczęściej koncentrowali się na dużych miastach, które trudno nazwać przygranicznymi. Program Litwa-Polska-Rosja także nie można zaliczyć do najbardziej zrównoważonych, ponieważ w bezpośrednim sąsiedztwie granicy nie ma licznych ośrodków miejskich. Dodatkowo obszar wsparcia jest dość duży w porównaniu do środków programu $^{31}$.

Liczba realizowanych projektów jest pochodną wielkości dostępnych środków finansowych w ramach poszczególnych programów. Średnia wielkość projektów była różna: od 159 tys. euro do 270 tys. euro. Konsekwencją tego była większa lub mniejsza koncentracja środków. Najniższy poziom koncentracji charakteryzował granicę wschodnią: na 40\% projektów przypadło ok. $75 \%$ środków ${ }^{32}$. Łączny budżet na 112 zrealizowanych projektów wynosił 23,49 mln euro ${ }^{33}$.

Struktura rodzajowa projektów wykazywała duże zróżnicowanie. Było one najbardziej zauważalne na najniższym poziomie podziału według kategorii interwencji. Wskazuje to, że uwarunkowania specjalistyczne dla poszczególnych

${ }^{29}$ Ex-Post Evaluation of Interreg 2000-2006 Initiative financed by the Regional Development Fund (ERDF), Final Report, Luxemburg 2010, s. 15.

30 Badanie ewaluacyjne ex-post efektów transgranicznej wspótpracy polskich regionów w okresie 2004-2006. Raport końcowy, PSDB na zlecenie Ministerstwa Rozwoju Regionalnego [online], http://www.funduszestrukturalne.gov.pl/Wiadomosci/Interreg+III/Znamy_efekty_wsp_ter_ 20042006 151010.htm (dostęp: 12.12.2010).

${ }^{3} 1$ Badanie ewaluacyjne ex-post efektów transgranicznej wspótpracy..., s. 43.

${ }^{32}$ Dla porównania na granicy zachodniej: na $40 \%$ projektów przypadło prawie $90 \%$ środków. Większość z tych środków wykorzystano na duże projekty infrastrukturalne o wysokiej kwocie dofinansowania.

${ }^{33}$ Badanie ewaluacyjne ex-post efektów transgranicznej współpracy..., s. 63. 
programów odgrywały ważną rolę. Przy czym na każdej granicy były one odmiennej natury. W programie Polska-Litwa-Rosja wynikały one w znacznej mierze z przyjętych rozwiązań formalnych. Na przykład z przyjęcia zasady partnera wiodącego, co przekładało się na przywiązywanie większej wagi do efektu transgranicznego i nastawienia programu na projekty „miękkie”. Najczęściej były to projekty z zakresu zasobów ludzkich lub naukowo-badawcze. Tym niemniej znaczący udział miały także te dotyczące infrastruktury edukacyjnej oraz obiektów turystycznych. Odnotować należy również istotną liczbę projektów infrastruktury drogowej, co może być skutkiem dużych potrzeb w tym zakresie wynikających z niskiej gęstości oraz jakości sieci drogowej. Generalnie stwierdzono, iż większość projektów było skierowanych na zaspokajanie najbardziej pilnych potrzeb lokalnych.

W strukturze beneficjentów zdecydowanie największy udział miały jednostki samorządu terytorialnego ze stosunkowo niskim udziałem gmin. Eksperci wnioskują, iż mogło to wynikać ze słabszego przygotowania gmin na tych obszarach do uczestnictwa w programie oraz mniejszej intensywności w kontaktach z partnerami po drugiej stronie granicy ${ }^{34}$. Istotny był udział projektów zgłaszanych przez szkoły z tego pogranicza, szczególnie w zakresie prowadzenia wymian młodzieży. Odnotowuje się także dużą aktywność organizacji pozarządowych, szczególnie instytucji kultury.

Poza tym pewne znaczenie miały uwarunkowania lokalne, w szczególności występowanie mniejszości narodowych po obu stronach granicy aktywnie działających na polu kulturalnym. W badaniu dostrzeżono, iż na pozostałych granicach wspomniane kwestie formalne nie odgrywały istotnej roli.

Najważniejsze efekty programów są następujące ${ }^{35}$ :

- programy wykazały istotny wpływ w obszarze budowania i utrwalania partnerstw pomiędzy instytucjami. Ze względu na dominujące znaczenie beneficjentów z jednostek samorządu terytorialnego program INTERREG stał się bardzo ważną platformą współpracy pomiędzy samorządami po obu stronach granicy;

- program współpracy transgranicznej na obszarze Polska-Litwa-Rosja odegrał ważną rolę w zakresie przełamywania negatywnych stereotypów narodowościowych;

- zrealizowane projekty zmniejszyły peryferyjność obszarów przygranicznych, w wyniku czego miało miejsce zwiększenie dostępu do usług publicznych, podniesienie jakości usług publicznych, zwiększenie bezpieczeństwa (lokalnie), integracji społecznej (lokalnie), podniesienia czystości środowiska (lokalnie), zwiększenia oferty spędzania wolnego czasu (lokalnie), zwiększenia możliwości zarobkowania (lokalnie) itd.;

- zwiększyła się przepustowość regionów, co zaowocowało zwiększeniem ruchu transgranicznego, osobowego i towarowego oraz ,przepustowość” dla in-

\footnotetext{
${ }^{34}$ Tamże, s. 57.

${ }^{35}$ Tamże, s. $120-122$.
} 
formacji (systemy monitorowania i wymiany informacji, w tym np. wspólne systemy rezerwacji turystycznej).

Mimo odnotowanego zmniejszenia różnic rozwojowych pomiędzy regionami leżącymi po obu stronach granicy podkreśla się, iż programy realizowane na polskich granicach nie koncentrowały się na wybranych obszarach priorytetowych współpracy transgranicznej, lecz stosowały szeroką strategię interwencji. W efekcie w przeważającej większości działania te odpowiadały na lokalne potrzeby, a nie koncentrowały środków na projektach przynoszących silny efekt transgraniczny. W dużej mierze wynikało to z tego, że skala finansowa programu INTERREG IIIA była nieporównywalnie mała w stosunku do innych programów działających w tym samym czasie w Polsce. Wysokość tych nakładów była zbyt mała, aby mówić o realnym wpływie tego programu na ogólne wskaźniki rozwoju obszarów przygranicznych. Podobnie oceniany jest wpływ programów współpracy transgranicznej w całej $\mathrm{UE}^{36}$.

\section{Podsumowanie}

Reasumując powyższe rozważania, można powiedzieć, iż współpraca transgraniczna w UE jest szczególnym przypadkiem współpracy międzynarodowej, której charakterystycznymi cechami są sąsiedzkość kontaktów oraz lokalny lub regionalny poziom współdziałania. Poprzez zapewnienie przepływu doświadczeń pomiędzy regionami z różnych państw wspiera ona działania zmierzające do podniesienia jakości funkcjonowania instytucji samorządowych, ułatwia rozwój turystyki, zapewnia koordynację rozbudowy infrastruktury po dwóch stronach granicy państwowej, prowadzi do kulturowego i edukacyjnego rozwoju regionu oraz integruje społeczeństwa lokalne. Wszystkie te funkcje spełniane przez współpracę transgraniczną sprawiają, że przyczynia się ona także do rozwoju gospodarczego.

Historia współpracy terytorialnej Polski, Litwy i Rosji sięga lat pięćdziesiątych, lecz dopiero w latach dziewięćdziesiątych zaczęła rozwijać się w aktywny sposób, kiedy Polska i Litwa przystąpiły do UE, a Obwód Kaliningradzki stał się wschodnią granicą wspólnot. Cechą charakterystyczną obszarów po obu stronach nowej granicy wschodniej UE jest ich peryferyjność, a współpraca transgraniczna na tym pograniczu od samego początku koncentrowała się na wspólnych problemach sąsiadujących ze sobą regionów, mając na celu uczynienie ich bardziej konkurencyjnymi i atrakcyjnymi, a także zniwelowanie różnic rozwojowych.

Kolejny impuls rozwojowy współpraca terytorialna otrzymała po rozszerzeniu UE w 2004 r. (okres programowy 2004-2006). Wówczas został uruchomiony nowy program wsparcia dla Obwodu Kaliningradzkiego i regionalnych sąsiadów

${ }^{36}$ Ex-Post Evaluation of Interreg 2000-2006 Initiative financed by the Regional Development Fund (ERDF), 2nd-Interim Report, Luxemburg 2010. 
z Litwy i Polski - Program Sąsiedztwa Litwa-Polska-Obwód Kaliningradzki. Od połowy lat dziewięćdziesiątych liczba inicjatyw, w których uczestniczyły regiony obszaru kwalifikowanego, stale rosła i osiągnęła na koniec 2006 r. liczbę 112, a łączny budżet zrealizowanych projektów wynosił $23,49 \mathrm{mln}$ euro. Nowy okres programowy wywołał potrzebę wypracowania nowej koncepcji politycznej dla krajów sąsiadujących z poszerzoną Unią, mającej na celu doskonalenie zasad prowadzenia współpracy. Budżet Programu na lata 2007-2013 ze środków Europejskiego Instrumentu Sąsiedztwa i Partnerstwa zwiększono do 132,13 mln euro.

Wpływ tego programu na regiony graniczne zbadano dla okresu 2004-2006 i stwierdzono, iż wykazał istotny wpływ na współpracę w obszarze budowania i utrwalania partnerstw pomiędzy instytucjami, w zakresie przełamywania negatywnych stereotypów narodowościowych oraz zmniejszenia peryferyjności i zwiększenia przepustowości obszarów przygranicznych. Jednocześnie należy odnotować, iż większość realizowanych przedsięwzięć kierowano na zaspokajanie najbardziej pilnych potrzeb lokalnych, przez co zabrakło tu silnego efektu transgranicznego. Uważa się, iż w dużej mierze wynikało to z tego, że skala finansowa programu INTERREG IIIA była stosunkowo mała w porównaniu do innych programów. Co prawda w nowym okresie programowania budżet tych programów znacznie wzrósł, co jest wynikiem wzrostu ogólnego funduszu środków przeznaczonych na realizację programów transgranicznych w ramach Europejskiej Współpracy Terytorialnej. Podstawowym wnioskiem z dotychczasowego przebiegu współpracy jest więc potrzeba koncentracji środków w ramach realizowanych programów transgranicznych na takich typach interwencji, które w sposób istotny przyczyniałyby się do uzyskania efektu transgranicznego. Tylko w ten sposób można osiągnąć większe korzyści dla wszystkich stron zaangażowanych we współpracę. 